\title{
PRODUCTIVE PERFORMANCE AND EGG QUALITY TRAITS OF LAYING HENS FED ON DIETS TREATED WITH NANO-SELENIUM UNDER HOT DESERT CONDITIONS
}

\author{
A. A. Elfiky(1), A. A. Enab(1), G. A. Zanaty(1), A. S. Morsy(2) \\ and H. Z. Sewalem ${ }^{(2)}$ \\ (1) Department of Poultry Production and fish, Faculty of Agriculture, University of \\ Menoufia, Shebin El Kom, Egypt. \\ (2) Animal and Poultry Physiology Department, Desert Research Center, Egypt.
}

Received: Jul. 27, 2021

Accepted: Aug. 1, 2021

ABSTRACT: The objective of this investigation was to study the productive performance of laying hens fed on diets treated with Nano-Selenium at various levels under hot desert conditions. One hundred and fifty 21-weeks-old purpose breeding hens of ISA White strain were distributed randomly into five treatments groups of $\mathbf{3 0}$ females. Each group was divided into 3 replicate (10 hens of each) the $1^{\text {st }}$ group was fed a basal diet without additives (control). The $2^{\text {nd }}, 3^{\text {rd }}$, and $4^{\text {th }}$ groups were fed the same basal diet supplemented with $0.1,0.2$ and $0.30 \mathrm{mg} \mathrm{Nano-Se} / \mathrm{kg}$ diet. The $5^{\text {th }}$ group was fed the same basal diet supplemented with $0.3 \mathrm{mg}$ organic-Sel $\mathrm{kg}$ diet (selenomethionine), respectively. Feed and water were provided ad-libitum throughout the experimental period (21-34 weeks of age). Artificial light was used beside the normal day light to provide 16 hourl day photo period. The results showed that egg number, egg weight, egg mass, and feed conversion ratio (FCR) were significantly ( $P \leq 0.05)$ improved by nano-se supplementation compared with hens fed the control diet. The best improvement in feed conversion noticed with birds which received $0.3 \mathrm{mg} / \mathrm{kg}$ diet nano-se. Body weight did not induce any significant differences among treatments. Showed the shell thickness, Egg width, $Y$ Width, and $Y H$ had significantly increased $(P \leq 0.05)$ by supplementation of source Se compared the control. On the other hand, shell weight and shell \% insignificantly differences in the hen's supplementation of source se compared the control. Also, albumen weight, albumen height, and yolk weight, egg index and egg weight were insignificantly differences in the hens as compared to the control.

In conclusion, under hot desert conditions, hens fed nano-selenium at a level of $0.2 \mathrm{mg}$ nano-sel $\mathrm{kg}$ diet might alleviate the drastic effect of heat stress and it's positively reflected on productive performance, and egg quality, economical efficiency and relative economical efficiency.

Key words: Nano-Selenium; Egg Production; Egg Quality; Laying Hens.

\section{INTRODUCTION}

Selenium is an essential trace element that has a large number of biological functions in poultry. Selenium is sometimes supplemented in broiler diets in its inorganic form (sodium selenite). However, this salt is very toxic and needs to be more soluble in its ionic form in order to increase its absorption in gastrointestinal tract. In addition, the electric charges of this ionic form may interact with other diet components (minerals, proteins and carbohydrates), rendering them partially unavailable to animals (Saad et al., 2013). Many researches study the various effects of using selenomethionine as organic selenium source in broiler or layer diets and most of them reported positive effects Mahmoud and Edens, (2003) and 
El-Sheikh and Ahmed (2006). Selenomethionine is the most appropriate form of se for use in animal nutritional supplements because of their excellent bioavailability and lower toxicity among various forms of se (Utterback et al., 2005). However, selenium deficiency in poultry causes oxidative diathesis, pancreatic dystrophy and nutritional muscle dystrophy of the gizzard, heart and skeletal muscle. Additionally, insufficient immunity, lowering of production ability, lowers fertility and laying capacity. Also, decreased feathering of chickens and increased embryonic mortality may occur due to selenium deficiency (Cantor and Scott 1974).

With the recent development of nanotechnology, nano-selenium (nanose) has attracted widespread attention because nanometer particulates exhibit novel characteristics such as a large surface area, high surface activity, high catalytic efficiency, strong adsorbing ability and low toxicity and it has been reported that nano-se possesses comparable efficiency to selenite and semethyl seleno cysteine in up regulating seleno enzymes but with dramatically decreased toxicity (Zhang et al., 2008). The different physiological effects of nano-se and sodium selenite were probably related to the different absorption process and metabolic pathways (Mohapatra et al., 2014 and b). It has been reported that nanoparticle show new characteristics of transport, uptake and exhibit higher absorption efficiencies (Liao et al., 2010). They suggested that the superior performance of nano particles may be attributed to their smaller particle size and larger surface area, increased mucosal permeability, improved intestinal absorption and tissue depositions. The transport efficiencies of selenomethionine and nano-se were higher than that of sodium selenite $(p \leq 0.05)$. The highest uptake efficiency $(p \leq 0.05)$ was observed in cells treated with nano-se and significant difference was also observed between the cells incubated with sodium selenite and selenomethionine (Wang and Fu, 2012). Glutathione peroxidase (GSH-Px ${ }^{\circledR}$ ) has antioxidative action and contributes to the oxidative defense by catalyzing the reduction of hydrogen peroxide and lipid peroxides to less harmful hydroxides (Arthur, 2000). The activity level of this enzyme in the liver or plasma is indicative of the se supply to the organism moreover antioxidant protection levels are affected by dietary se status (Wang and $X u, 2008$ ).

Therefore, the objective of this investigation was to study productive performance and egg quality of laying hens fed on diets treated with at various levels nano-selenium under hot desert conditions.

\section{MATERIALS AND METHODS}

The present study was conducted in the Poultry Research Farm, Al Sarhan Farm located at Bir AL Abed in North Sinai, Egypt. The experiment started on June 2017 up to August 2017. Laboratory work was carried out in the laboratories compound of Desert Research Center.

\section{Experimental design}

One completely randomized design was carried out to study effects of dietary supplementation of nano selenium (0.1, 0.2 , and $0.3 \mathrm{mg} / \mathrm{kg}$ diet) and organic selenium (0.3 $\mathrm{mg} / \mathrm{kg} \mathrm{diet})$ on the productive and physiological performance of ISA strain layers under hot desert conditions in Egypt. A total number of 150 ISA white strain layers (21weeks old and body weight of $1252.8 \mathrm{~g} \pm$ 9.3) were randomly divided into five equal experimental groups (30 layers/ group). Each group was randomly divided into 3 equal replicates (10 hens of each). The $1^{\text {st }}$ 
group ( $\left(\mathrm{Tr}_{1}\right)$, hens fed basal diet without additives (control). The $2^{\text {nd }}, 3^{\text {rd }}$ and $4^{\text {th }}$ groups $\left(\mathrm{Tr}_{2}, \mathrm{Tr}_{3}\right.$ and $\mathrm{Tr}_{4}$ ) layers fed the same basal diet supplemented with 0.1 , 0.2 and $0.3 \mathrm{mg}$ nano selenium/ $\mathrm{kg}$ diet, respectively. The $5^{\text {th }}$ group $\left(\mathrm{Tr}_{5}\right)$, fed the basal diet, supplemented with $0.3 \mathrm{mg}$ organic selenium/ kg diet.

\section{Preparation and characterization of selenium nano particles:}

Selenium nano particles were prepared by the reduction of selenium with diluted aqueous solutions containing $\quad \mathrm{Na}_{2} \mathrm{SO}_{3} . \quad$ Sodium selenosulphate solution was prepared by refluxing a mixture of selenium and $\mathrm{Na}_{2} \mathrm{SO}_{3}$ in double distilled water at 70-80 ${ }^{\circ} \mathrm{C}$ for about 7-8 hours (Gorer and Hodes, 1994). An aqueous polyvinyl alcohol (PVA) stock solution, $1 \%$ by weight, was prepared and used as stabilizing agent. The formation of orange-red colored selenium nano particle solution was observed in less than one minute upon mixing the PVA with Sodium selenosulphate. It is important to use stabilizer, during the preparation of metal nano-particle, to avoid nano-particles agglomeration (Bai et al., 2007).

\section{Characterization:}

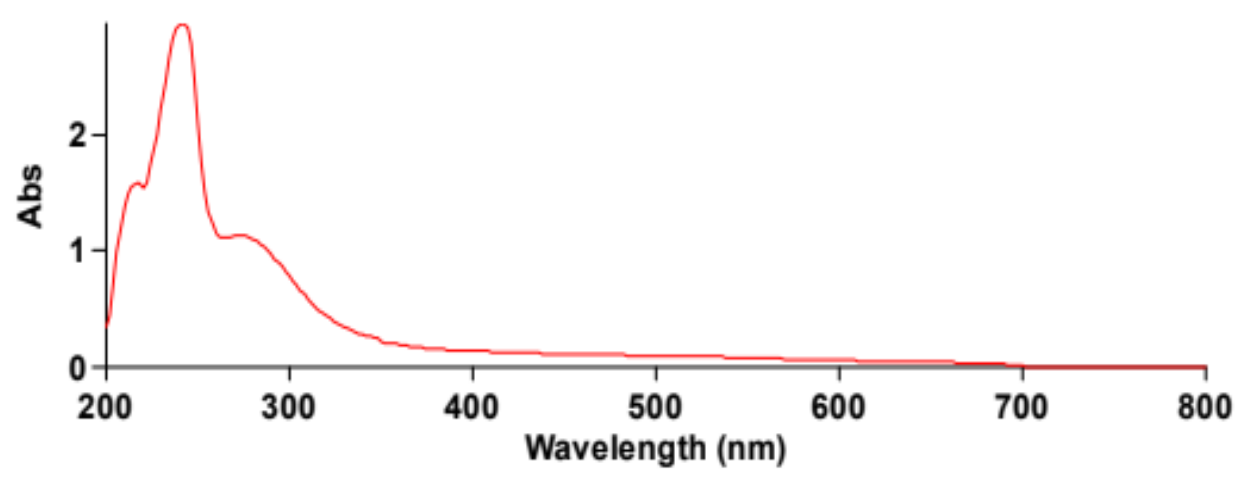

Figure 1: UV-V spectroscopy of nano selenium. 
A. A. Elfiky, et al.,

Table (1): Ingredients and chemical analysis of the control basal diet:

\begin{tabular}{|c|c|c|c|}
\hline Ingredients & Basal diet & Calculated values ${ }^{3}:$ & \\
\hline Yellow corn (8.8\%) & 58.02 & Crude protein, \% & 18.02 \\
\hline Soybean meal (44\%) & 29.34 & ME, Kcal/ kg diet & 2797 \\
\hline Vegetable oil & 2.17 & C/P ratio & 155.2 \\
\hline Di-calcium phosphate & 1.32 & Lysine, \% & 0.80 \\
\hline Limestone, ground & 8.39 & Methionine, \% & 0.41 \\
\hline Vit. and Min. Mix. ${ }^{1}$ & 0.30 & Met.+ Cysteine, \% & 0.66 \\
\hline DL- methionine ${ }^{2}$ & 0.15 & Calcium, \% & 3.46 \\
\hline Salt & 0.31 & Av. Phosphorus, \% & 0.42 \\
\hline Total & 100 & & \\
\hline
\end{tabular}

${ }^{1}$ Vitamins and minerals premix provided per kilogram of the diet: Vit. A, $1200 \mathrm{IU} ;$ Vit. $\mathrm{D}_{3}, 2500 \mathrm{IU}$; Vit E, $10 \mathrm{mg}$; Vit. K, $3 \mathrm{mg}$; Vit. B1, $1 \mathrm{mg}$; Vit. B2, $4 \mathrm{mg}$; Pantothenic acid, $10 \mathrm{mg}$; Nicotinic acid, $20 \mathrm{mg}$; Folic acid, $1 \mathrm{mg}$; Biotin, $0.05 \mathrm{mg}$; Niacin, $40 \mathrm{mg}$; Vit. $B_{6}, 3 \mathrm{mg}$; Vit. $B_{12}, 0.02 \mathrm{mg}$; Choline chloride, $500 \mathrm{mg}$; Mn., $62 \mathrm{mg}$; Fe., $30 \mathrm{mg}$; Zn., $56 \mathrm{mg}$; l., $1 \mathrm{mg}$; ${ }^{2} \mathrm{DL}$ - methionine: 98 \% feed grade (contained $98 \%$ methionine). ${ }^{3}$ Calculated according to NRC (1994).

\section{Investigated measurements:}

Temperature-humidity index:

Indoor (ambient temperature and relative humidity index were recorded during the experimental period (Table 2). Temperature Humidity Index (THI) calculated according to Marai et al. (2001). They reported that $\mathrm{THI}=\mathrm{db}^{\circ} \mathrm{C}-$ [(0.31 - $\left.0.31 \times \mathrm{RH}) \times\left(\mathrm{db}^{\circ} \mathrm{C}-14.4\right)\right]$. Where, $\mathrm{db}^{\circ} \mathrm{C}=$ dry bulb temperature in centigrade, The THI values were classified as absence of heat stress ( $\leq 27.8)$, moderate heat stress (27.8-28.8), severe heat stress (28.9-29.9) and very severe heat stress $(\geq 30.0)$.

\section{Productive performance}

Body weight was recorded at initial body weight (21 weeks) and at final body weight (34 weeks). Egg number and egg weight were daily recorded for 90 days (egg production period). Egg mass was calculated by multiplying average egg weight by egg number. Feed and water intake were recorded. Feed conversion ratio was calculated as follows: feed conversion ratio=total feed intakel total egg mass.

\section{Egg quality}

Thirty eggs were randomly collected from each treatment (180 eggs) to measure egg quality traits according to Stino et al. (1982) and El -Wardany et al. (1994). These traits included that: Egg shape index $=$ egg width/egg length $\times 100$ using Vernier Caliper for measurements. Egg shell weight was recorded by digital balance to nearest 0.1 gram. Shell (\%) = shell weight $/$ egg weight $\times 100$. Egg shell thickness measured with membrane in $\mathrm{mm}$ (average of the broad, narrow ends and equator areas of egg). Yolk weight was recorded by digital balance to nearest 0.1 gram. Yolk $(\%)=$ yolk weight $I$ egg weight $\times 100$. Yolk index calculated as yolk height $I$ yolk diameter $\times 100$. Albumen weight was calculated by subtracting yolk and shell weight from total egg weight. Albumen (\%) $=$ albumen weight / egg weight $\times 100$. Yolk / Albumen ratio $=$ yolk weight $I$ albumen weight $\times$ 100. 


\section{Economical efficiency:}

Economic efficiency for egg production was calculated from the input-output analysis (Heady and Jensen, 1954) according to the price of the experimental diets and egg produced. Values of economic efficiency were calculated as the net revenue per unit of total costs (Soliman and Abdo, 2005).

\section{Chemical analysis:}

At 34 weeks of age, three eggs from each treatment group were randomly taken for chemical analysis, and then samples were oven dried at $105^{\circ} \mathrm{C}$, then ground and stored to chemical analysis. The determination of moisture, crude protein, ether extract and crude fiber in eggs were carried out according to the Official Methods (AOAC, 2003).

\section{Statistical analysis}

Data was analyzed on one way classification basis by the least square analysis of variance using the General Linear Model Procedure (SAS, 2004). The model was as follows:
$Y_{i j}=\mu+T_{i}+e_{i j}$

$Y_{i j}=$ Any observations of $i^{\text {th }}$ hen within $j^{\text {th }}$ treatment

$\mu=$ Overall mean

$T_{i}=$ Effect of $i^{\text {th }}$ treatment, (i: 1-5)

$\mathbf{e}_{\mathrm{ij}}=$ Random error .

All statements of significance are based a probability of less than 0.05 . Significant differences among means were tested using Duncan multiple range test (Duncan, 1955).

\section{RESULTS AND DISCUSSION}

\section{Productive Performance}

Results in Table (3) showed that supplementation of nano-se (Tr2 and Tr3) and organic-se (Tr4) had insignificantly increased final body weight and body weight change as compared to the hens in control group. Similar findings were also reported by Zhou and Wang, (2011); Cai et al., (2012) they reported no significant effect of supplementation nano-se $(0.2,0.3$ and $0.5 \mathrm{mg} / \mathrm{kg} \mathrm{diet})$ or organic-se on body weight of broilers chicks.

Table (2): Indoor ambient temperature (AT), relative humidity (RH) and temperaturehumidity index (THI) during experimental period:

\begin{tabular}{lcccccc}
\hline \multirow{2}{*}{ Month } & $\begin{array}{c}\text { Min } \\
\text { AT }\left({ }^{\circ} \mathrm{C}\right)\end{array}$ & $\begin{array}{c}\text { Max } \\
\text { A }\left({ }^{\circ} \mathrm{C}\right)\end{array}$ & $\begin{array}{c}\text { Min } \\
\text { RH }(\%)\end{array}$ & $\begin{array}{c}\text { Max } \\
\text { RH }(\%)\end{array}$ & $\begin{array}{c}\text { Min } \\
\text { THI }\end{array}$ & $\begin{array}{c}\text { Max } \\
\text { THI }\end{array}$ \\
\hline June & $26.93 \pm 0.27$ & $32.86 \pm 0.21$ & $41.30 \pm 1.08$ & $71.20 \pm 0.85$ & $25.81 \pm 0.25$ & $29.50 \pm 0.17$ \\
July & $25.48 \pm 0.27$ & $32.61 \pm 0.20$ & $37.90 \pm 1.06$ & $72.16 \pm 0.84$ & $24.53 \pm 0.25$ & $29.10 \pm 0.17$ \\
Aug & $27.64 \pm 0.27$ & $33.64 \pm 0.20$ & $43.41 \pm 1.06$ & $71.51 \pm 0.84$ & $26.46 \pm 0.25$ & $30.26 \pm 0.17$ \\
\hline Overall & $26.68 \pm 0.18$ & $33.04 \pm 0.12$ & $40.86 \pm 0.65$ & $71.63 \pm 0.48$ & $25.60 \pm 0.16$ & $29.62 \pm 0.11$ \\
\hline
\end{tabular}

Table (3). Body weight and body weight change of laying hens as affected by organic and nano selenium supplementation.

\begin{tabular}{lllllll}
\hline Traits & $\mathrm{C}$ & $\operatorname{Tr}_{1}$ & $\operatorname{Tr}_{2}$ & $\operatorname{Tr}_{3}$ & $\operatorname{Tr}_{4}$ & $\pm S E$ \\
\hline IBW (g) & 1253.75 & 1253.70 & 1252.20 & 1252.00 & 1252.50 & 21.27 \\
FBW (g) & 1448.43 & 1443.03 & 1475.29 & 1477.42 & 1459.37 & 13.52 \\
BWC (g) & 194.68 & 189.32 & 223.08 & 225.42 & 206.87 & 23.94 \\
\hline
\end{tabular}

$\mathrm{C}=$ control (hens fed $0.3 \mathrm{mg}$ inorganic selenium/ $\mathrm{kg}$ diet; $\operatorname{Tr}_{1}=$ hens fed $0.1 \mathrm{mg}$ nano selenium/ $\mathrm{kg}$ diet; $\operatorname{Tr}_{2}=$ hens fed $0.2 \mathrm{mg}$ nano selenium/ kg diet; $\operatorname{Tr}_{3}=$ hens fed $0.3 \mathrm{mg}$ nano selenium/ $\mathrm{kg}$ diet; $\mathrm{Tr}_{4}$ $=$ hens fed $0.3 \mathrm{mg}$ organic selenium/ $\mathrm{kg}$ diet. $\pm \mathrm{S}$.E, standard error; IBW = initial body weight, FBW = final body weight, BWC $=$ body weight change. 
Data presented in Table (4) showed that there was a significant $(P \leq 0.05)$ increase in the value of egg weight of the hen's received diet supplemented with $0.3 \mathrm{mg}$ of nano-se $\left(\mathrm{Tr}_{3}\right)$ as compared to the control group. The higher egg weight was observed with hens received $0.3 \mathrm{mg}$ nano-sel $\mathrm{kg}$ diet $\left(\mathrm{Tr}_{3}\right)$ by $4.1 \%$ as compared to the hens in control group. Likewise, egg number and egg mass were significantly $(P \leq 0.05)$ increased in the hens of $\mathrm{Tr}_{3}(0.3 \mathrm{mg}$ nano-sel $\mathrm{kg}$ diet) and $\mathrm{Tr}_{2}$ ( $0.2 \mathrm{mg}$ nano-se/ $\mathrm{kg}$ diet) groups, followed by hens when compared to the control group and other dietary treatment groups.The higher egg mass was observed with hens received diet containing $0.3 \mathrm{mg}$ nano-sel $\mathrm{kg}$ diet value by $19.5 \%$ as compared to the hens in control group. The effect of selenium supplementation on feed conversion of hens is presented in Table (4). It can be noticed that feed conversion ratio of hens was significantly improved by selenium supplementation at 0.2 and 0.3 $\mathrm{mg} / \mathrm{kg}$ diet. The finest improvement in feed conversion was noticed with hens which received diet containing $0.3 \mathrm{mg}$ nano-sel kg diet. It can be noted that feed intake of hens was significantly improved by selenium supplementation at $0.2 \mathrm{mg} /$ $\mathrm{kg}$ diet. These results agree with the results of Fu-xiang et al., (2008); Selim et al., (2015). They reported improvement FCR of broiler chicks when fed containing supplemental se sources using organic or nano-se $(0.15,0.2,0.3$, 0.4 and $0.5 \mathrm{mg} / \mathrm{kg}$ diet). The improvement for productive performance may be attributed to selenium supplementation, where se is an important auxiliary factor for the key enzyme of 5-deiodinase (Nadia et al., 2015; Rizk et al., 2017).

\section{Egg quality}

The results in Table (5) showed the shell thickness and yolk color had significantly $(P \leq 0.05)$ increased by supplementation of se source as compared the control group. Shell thickness had significantly ( $P \leq 0.05)$ increased by 24.5, 21.6, 19.0 and $16.8 \%$ for $\mathrm{Tr}_{1}, \mathrm{Tr}_{2}, \mathrm{Tr}_{3}$ and $\mathrm{Tr}_{4}$ groups, respectively as compared to the hens of control group. These results agree with the results of Sara et al., (2008); Maysa et al., (2009) they showed that shell thickness was significantly increased in Sel-Plex ${ }^{\mathrm{TM}}$ treated groups compared to the control group. However, Gjorgovska et al., (2012) reported that percentage of yolk, albumin and shell egg were not affected by different levels or sources of selenium. On the other hand, shell weight and shell \% insignificantly differences in the hen's supplementation of source se compared the control. Also, albumen weight, albumen height, and yolk weight, egg index and egg weight were insignificantly differences in the hens of $\mathrm{Tr}_{1}, \mathrm{Tr}_{2}, \mathrm{Tr}_{3}$ and $\mathrm{Tr}_{4}$ as compared to the control. These results agree with the results of Gjorgovska et al., (2012) they reported that percentage of yolk, albumin and shell egg were not affected by different levels or sources of Selenium. On the other hand, Maysa et al., (2009) and Rizk et al., (2017) evaluated the $1^{\text {st }}$ egg weight significantly increased for groups fed diet of nano and organic-se values by $(12.5 \%$, and $8.6 \%)$ than those of the control. They also showed improve in egg yolk index was significantly increased for hens fed sel-plex supplementation compared with those in control group. 
Table (4). Productive performance of laying hens as affected by organic and nano selenium supplementation.

\begin{tabular}{lllllll}
\hline Traits & $\mathrm{C}$ & $\operatorname{Tr}_{1}$ & $\operatorname{Tr}_{2}$ & $\operatorname{Tr}_{3}$ & $\operatorname{Tr}_{4}$ & $\pm \mathrm{SE}$ \\
\hline EW (g) & $54.91^{\mathrm{b}}$ & $55.66^{\mathrm{ab}}$ & $56.66^{\mathrm{ab}}$ & $57.16^{\mathrm{a}}$ & $55.41^{\mathrm{ab}}$ & 0.65 \\
EN & $57.08^{\mathrm{d}}$ & $59.66^{\mathrm{c}}$ & $64.75^{\mathrm{a}}$ & $65.58^{\mathrm{a}}$ & $62.41^{\mathrm{b}}$ & 0.77 \\
EM (g) & $3136.66^{\mathrm{c}}$ & $3321.83^{\mathrm{b}}$ & $3666.00^{\mathrm{a}}$ & $3748.58^{\mathrm{a}}$ & $3460.33^{\mathrm{b}}$ & 59.13 \\
DFI (g) & $108.44^{\mathrm{a}}$ & $103.31^{\mathrm{b}}$ & $104.40^{\mathrm{b}}$ & $105.94^{\mathrm{ab}}$ & $106.68^{\mathrm{ab}}$ & 1.23 \\
TFI (g) & $9759.75^{\mathrm{a}}$ & $9298.50^{\mathrm{b}}$ & $9396.00^{\mathrm{b}}$ & $9534.75^{\mathrm{ab}}$ & $9601.50^{\mathrm{ab}}$ & 111.29 \\
FC & $3.126^{\mathrm{a}}$ & $2.811^{\mathrm{b}}$ & $2.569^{\mathrm{c}}$ & $2.545^{\mathrm{c}}$ & $2.782^{\mathrm{b}}$ & 0.05 \\
\hline
\end{tabular}

$\mathrm{C}=$ control (hens fed $0.3 \mathrm{mg}$ inorganic selenium/ $\mathrm{kg}$ diet; $\mathrm{Tr}_{1}$ =hens fed $0.1 \mathrm{mg}$ nano selenium/ $\mathrm{kg}$ diet; $\mathrm{Tr}_{2}=$ hens fed $0.2 \mathrm{mg}$ nano selenium $/ \mathrm{kg}$ diet; $\mathrm{Tr}_{3}=$ hens fed $0.3 \mathrm{mg}$ nano selenium/ $\mathrm{kg}$ diet; $\mathrm{Tr}_{4}$ $=$ hens fed $0.3 \mathrm{mg}$ organic selenium/ $\mathrm{kg}$ diet. $\pm \mathrm{S} . \mathrm{E}$, standard error; $\mathrm{EW}=$ egg weight, $\mathrm{EN}=$ egg number, $\mathrm{DFI}=$ daily feed intake, $\mathrm{TFI}=$ total feed intake, $\mathrm{EM}=$ egg mass, $\mathrm{FC}=$ feed conversion. ${ }^{\mathrm{a}} \mathrm{b}, \mathrm{c}$ Means bearing different superscripts within the same row are significantly different $(P \leq 0.05)$.

Table (5): Egg quality parameters of laying hens as affected by organic and nano selenium supplementation.

\begin{tabular}{lllllll}
\hline Traits & $\mathrm{C}$ & $\mathrm{Tr}_{1}$ & $\mathrm{Tr}_{2}$ & $\mathrm{Tr}_{3}$ & $\mathrm{Tr}_{4}$ & $\pm \mathrm{SE}$ \\
\hline Egg weight (g) & 54.65 & 53.97 & 55.99 & 55.11 & 57.17 & 1.22 \\
Egg shape index & 73.56 & 73.14 & 73.02 & 73.96 & 74.40 & 111.29 \\
Yolk index & 43.52 & 44.35 & 43.06 & 44.01 & 45.34 & 1.32 \\
Albumen height & 6.97 & 7.09 & 6.55 & 7.20 & 7.50 & 0.45 \\
Yolk weight (g) & 12.92 & 12.81 & 13.71 & 12.90 & 13.34 & 0.63 \\
Yolk (\%) & 23.75 & 23.67 & 24.55 & 23.30 & 23.43 & 1.06 \\
Yolk color & $6.00^{\mathrm{b}}$ & $6.84^{\mathrm{ab}}$ & $7.00^{\mathrm{ab}}$ & $7.76^{\mathrm{a}}$ & $6.23^{\mathrm{b}}$ & 0.45 \\
Albumen weight (g) & 34.43 & 34.00 & 34.87 & 34.88 & 36.13 & 1.11 \\
Albumen (\%) & 63.85 & 62.95 & 62.20 & 63.28 & 63.09 & 1.11 \\
Shell (\%) & 13.38 & 13.37 & 13.23 & 13.41 & 13.45 & 0.49 \\
Shell thickness (×0.01 $\mathrm{mm})$ & $0.416^{\mathrm{b}}$ & $0.495^{\mathrm{a}}$ & $0.506^{\mathrm{a}}$ & $0.518^{\mathrm{a}}$ & $0.486^{\mathrm{a}}$ & 0.01 \\
\hline
\end{tabular}

$\mathrm{C}=$ control (hens fed $0.3 \mathrm{mg}$ inorganic selenium $/ \mathrm{kg}$ diet; $\mathrm{Tr}_{1}=$ hens fed $0.1 \mathrm{mg}$ nano selenium/ $\mathrm{kg}$ diet; $\mathrm{Tr}_{2}=$ hens fed $0.2 \mathrm{mg}$ nano selenium $/ \mathrm{kg}$ diet; $\mathrm{Tr}_{3}=$ hens fed $0.3 \mathrm{mg}$ nano selenium $/ \mathrm{kg}$ diet; $\mathrm{Tr}_{4}$ $=$ hens fed $0.3 \mathrm{mg}$ organic selenium $/ \mathrm{kg}$ diet. $\pm \mathrm{SE}=$ standard error. $\mathrm{a}, \mathrm{b}, \mathrm{c}$ Means bearing different superscripts within the same row are significantly different $(P \leq 0.05)$.

\section{Economical efficiency:}

Results concerning economical efficiency evaluation of nano-se and organic-se incorporation in ISA white layer hens diets are shown in Table (6).

Generally, the results indicate that supplementation of nano-se and organicse increases economical efficiency and relative economical efficiency. The best values were obtained with $0.2 \mathrm{mg}$ nanosel kg diet.
The highest economical efficiency value $(168.46 \%)$ was observed with the diet containing $0.2 \mathrm{mg}$ nano-se/ $\mathrm{kg}$ diet (T2), followed by (157.73 \%) the diet containing $0.3 \mathrm{mg}$ nano-sel $\mathrm{kg}$ diet (T3) and lowest economical efficiency value (132.69 \%) obtained with the control (C). The relative economical efficiency values followed the same trend being highest for (T2) and lowest in control (C). 
A. A. Elfiky, et al.,

Table (6). Economical evaluation of laying hens as affected by organic and nano selenium supplementation.

\begin{tabular}{llllll}
\hline Traits & C & Tr1 & Tr2 & Tr3 & Tr4 \\
\hline Feed conversion & 3.126 & 2.811 & 2.569 & 2.545 & 2.782 \\
Cost of kg feed (L.E) & 5.50 & 5.70 & 5.80 & 6.10 & 5.70 \\
Feed cost of kg egg (L.E) & 17.19 & 16.02 & 14.90 & 15.52 & 15.86 \\
Selling price of one kg egg (L.E) & 40.00 & 40.00 & 40.00 & 40.00 & 40.00 \\
Net revenue (L.E) & 22.81 & 23.98 & 25.10 & 24.48 & 24.14 \\
Economic efficiency & 132.69 & 149.69 & 168.46 & 157.73 & 152.21 \\
Relative economic efficiency (\%) & 100.00 & 112.81 & 126.96 & 118.87 & 114.71 \\
\hline
\end{tabular}

$\mathrm{C}=$ control (hens fed $0.3 \mathrm{mg}$ inorganic selenium / $\mathrm{kg}$ diet; $\mathrm{Tr} 1$ =hens fed $0.1 \mathrm{mg}$ nano selenium / $\mathrm{kg}$ diet; Tr2 =hens fed $0.2 \mathrm{mg}$ nano selenium / kg diet; Tr3 =hens fed $0.3 \mathrm{mg}$ nano selenium / $\mathrm{kg}$ diet; Tr4 =hens fed $0.3 \mathrm{mg}$ organic selenium $/ \mathbf{~ k g}$ diet. Economic efficiency = (Net revenue $\div$ Total feed cost) $x$ 100. Relative economic efficiency of control considered 100.

Bai, J., Y. Li, J. Du, S. Wang, J. Zheng, Q. Yang and $X$. Chen (2007). One- pot synthesis of polyacrylamide-gold Nano composite. Mater. Chem. Phys., 106(2-3): 412-415.

Cai, S. J., C. X. Wu, L. M. Gong, T. Song, T. H. Wu and L. Y. Zhang (2012). Effects of Nano-selenium on performance, meat quality, immune function, oxidation resistance and tissue selenium content in broilers. Poultry Sci., 91: 2532-2539.

Cantor, A. H. and M. L. Scott (1974). The effect of selenium in the hen's diet on egg production, hatchability, performance of progeny and selenium concentration in eggs. Poult. Sci., 53: 1870-1880. Egyptian Poultry Science, 25: 317 - 331.

Duncan, D. B. (1955). Multiple Range and Multiple F Test. Biometrics 11: 1 - 42.

El-Sheikh, A. M. H., E. A. Abdalla and M. Hanafy (2010). The effect of organic selenium supplementation on productive and physiological performance in a local strain of chicken. 2- immune system and some physiological aspects in bandarah chicks affected by organic selenium. Egyptian Poultry Science., 30(2): 517533.

\section{CONCLUSION}

Under hot desert conditions, layer hens fed on nano-selenium at a level of $0.2 \mathrm{mg}$ nano-sel $\mathrm{kg}$ diet might alleviate the drastic effect of heat stress and it's positively reflected on productive performance, egg quality and economic efficiency.

\section{Acknowledgments}

Deepest thanks are due to Dr. Ahmed Lotfy Hashem for facilitating the research work. Deepest thanks are due to Poultry Research Farm and the Poultry Nutrition, All Sarhan farm in Bir AL Abed in North Sinai Staff for contributed during sample collection.

\section{REFERENCES}

AOAC, (2003). Association of Official Analytical Chemists, pages 57-58 Official Methods of Analysis, 16th ed. Washington DC.

Arthur, J. R. (2000). The glutathione peroxidases. Cell. Mol. Life Scie., 57: 1825-1835.

Arthur, J.R. and G.J. Beckett (1999). Thyroid function. Br. Med Bull., 55: 658-668. 
Maysa, M. Hanafy, A. M. H. El-Sheikh and E. A. Abdalla (2009). The effect of organic selenium supplementation productive and physiological performance in a local strain of chicken. 1- The effect of organic selenium (Sel-Plex) on productive, reproductive and physiological traits of bandarah local strain. Egypt. Poult. Sci., vol (29) (IV): (1061-1084).

Mohapatra, P., R. K. Swain, S. K. Mishra, T. Behera, P. Swain, S. S. Mishra, N. C. Behura, S. C. Sabat, K. Sethy, K. Dhama and P. Jayasankar (2014ª). Effects of dietary Nano-selenium on tissue selenium deposition, antioxidant status and immune functions in layer chicks. Int. J. Pharmacol., 10: 160-167.

Mohapatra, P., R. K. Swain, S. K. Mishra, T. Behera, P. Swain, N. C. Behura, G. Sahoo, K. Sethy, B. P. Bhol and K. Dhama $\left(2014^{b}\right)$. Effects of dietary Nano-Selenium supplementation on the performance of layer grower birds. Assian J. of Animal and Veterinary Advances 9(10): 641-652.

Nadia, L. Radwan, T. A. Salah Eldin, A. A. EL-Zaiap and Mona A. A. Mostafa (2015). Effect of Dietary NanoSelenium Supplementation on Selenium Content and Oxidative Stability in Table Eggs and Productive Performance of Laying Hens. International Journal of Poultry Science., 14 (3): 161-176.

Rizk, Y. S., A. F. Ibrahim, K. Mogda; Mansour; S. Hanan; Mohamed; A. E. El-Slamony and A. A. M. Soliman (2017). Effect of dietary source of seleniumon productive and reproductive performance of sinai laying hens under heat stress conditions. Egypt. Poult. Sci., Vol (37) (II): (461-489).

Saad, M. B., L. R. S. Gertner, L. N. Kuritza, R. M. Hayashi, L. Pickler and E. Santin (2013). The effect of organic selenium
El-Sheikh, T. M. and S. Ahmed-Nagwa (2006). An attempt to alleviate heat stress of broiler chicks (during summer season) through stocking density, dietary organic selenium (SelPlex) and vitamin E-selenium. Egypt Poult Sci., 26:1587-1611.

El-Wardany, A. M., L. M. Goher and A. A. Enab (1994). Effect of breed, laying period and selection for egg weight on egg Quality in two local breeds of chickens. Egypt Poultry Science., 14: 23-49.

Evaluation of fresh garlic as natural feed additive in layer diets varying in energy content.

Fu-xiang, W., R. Huiying, Z. Fenghua, S. Jinquan, J. Jianyang and L. Wenli (2008). Effects of Nano-Selenium on the Immune Functions and Antioxidant.

Gorer, S. and G. Hodes (1994). Quantum size effects in the study of chemical solution deposition mechanisms of semiconductor films. J. Physical Chemistry, vol. 98, no. 20, 5338-5346.

Gjorgovska, N., F. Kiril, L. Vesna and K. Tosho (2012). The effectof dietary levels of selenium in feed on egg production, eggquality and selenium ontent in yolkLucrari Stiintifice -Seria Zootehnie.,57: 270-274.

Liao, C. D., W. L. Hung, K. C. Jan, A. I. Yeh, C. T. Ho and L. S. Hwang (2010). Nano sub microsized lignan glycosides from sesame meal exhibit higher transport and absorption efficiency in caco-2 cell monolayer. Food chem., 119: 896-902.

Mahmoud, K. Z. and F. W. Edens (2003). Influence of selenium sources on age related and mild heat stress-related changes of blood and liver glutathione redox cycle in broiler chickens (Gallus domesticus). Comparative Biochem. And Phys., in the Caco-2 cell model. Biolo. Trace Element 136: 921- 934. 
Utterback, P. L., C. M. Parsons, I. Yoon and J. Butler (2005). Effect of supplementing selenium yeast in diets of laying hens on egg selenium content. Poult. Sci., 84: 1900-1901.

Wang, Y. and L. Fu (2012). Forms of selenium affect its transport, uptake and glutathione peroxidase activity in the Caco-2 cell model. Biolo. Trace Element Res., 149: 110-116.

Wang, Y. B. and B. H. Xu (2008). Effect of different selenium source (sodium selenite and selenium yeast) on broiler chickens. Anim. Feed Sci., Tech., 144: 306-314.

Zhang, J. S., X. F. Wang and T. W. Xu (2008). Elemental selenium at nano size (Nano-Se) as a potential chemo preventive agent with reduced risk of selenium toxicity: Comparison with Semethyl selenocysteinein mice. Toxicological Science., 101: 22-31.

Zhou, X. and Y. Wang (2011). influence of dietary Nano elemental selenium on growth performance, tissue selenium distribution, meat guality, and glutathione peroxidase activity in Guangxi yellow chicken. Poultry Science., 90(3): 680-686. supplementation on the broilers immune response. Iranian $J$. of Applied Animal Sci., 3 (1): 113-118.

Sara, A., M. Bennea, A. Odagiu and L. Panta (2008). Effect of the organic selenium (Sel-Plex) administred in laying hens's feed in second laying phase on production performances and the eggs quality. Bulletin UASVM Animal Science and Biotechnologies, 65:12.

SAS, (2004). SAS User's Guide: Statistics. Release 9.1. SAS Institute Incorporated., Cary, North Carolina.

Selim, N. A., N. L. Radwan, S. F. Youssef, T. A. Salah Eldin and S. Abo Elwata (2015). Effect of inclusion inorganic, organic or Nano-selenium forms in broiler diets on: 2-Physiological, immunological and toxicity statuses of broiler chicks. International Journal of Poultry Science., 14 (3): 144-155.

Stino, F. K., N. E. Goher, G. A. Kamar and N. A. Hanash (1982). The effect of breed and housing system on the egg quality of White Baladi and Fayoumi hens in the subtropics. Egyptian Journal Animal Production, 23: 191198. 
الأداء الإنتاجي وصفات جودة البيض للاجاج البياض المعامل بالنانو سيلينيوم تحت الظروف الصحراوية الحارة

عبد المنعم عبد الحليم الفقى(')، أحمد عبد الوهاب عنب(') ، جمال عبد الستار زناتي(')،

$$
\begin{aligned}
& \text { على صابر مرسي (r)، حسام زاهر سويلم(r) } \\
& \text { (1) قسم إنتاج الدواجن والأسماك - كلية الزراعة - جامعة المنوفية - شبين الكوم - مصر . }
\end{aligned}
$$

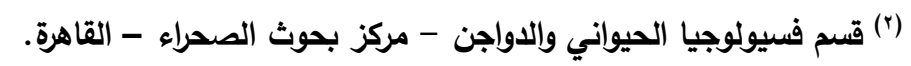

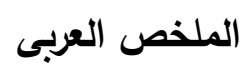

الهاف من هذا البحث هو دراسة الأداء الإنتاجي للاجاج البياض المعامل بالنانو سيلينيوم تحت ظروف الصحراوية

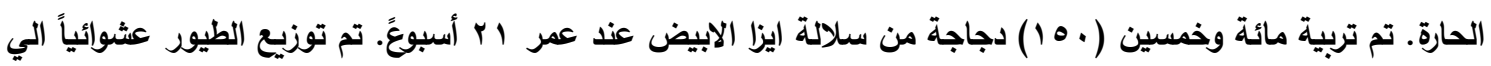

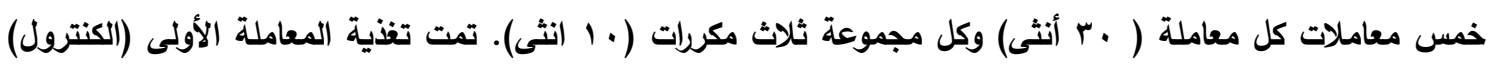

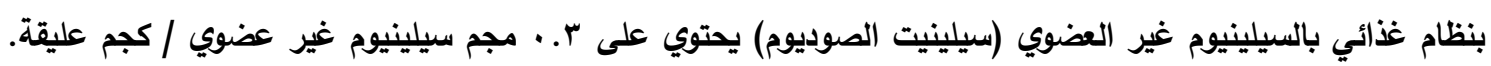

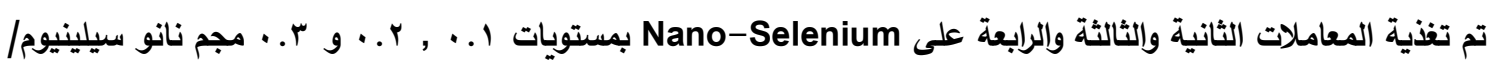

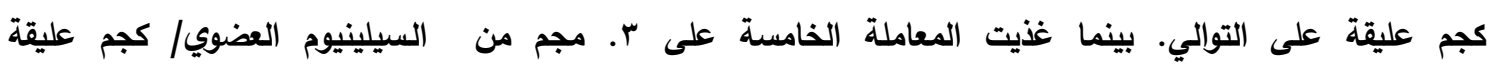

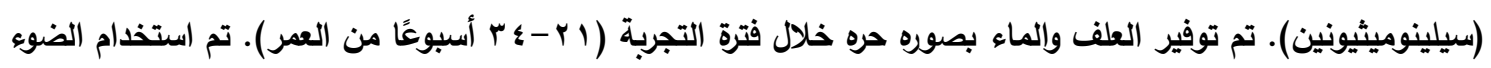

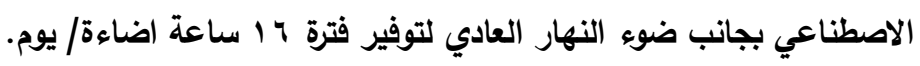

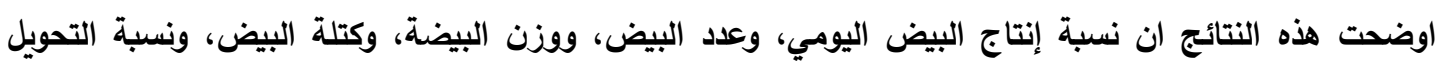
الغذائي (FCR) تحسنت معنويا (P 0.05) بين المعاملات باستخدام النانو سيلينوم مقارنة مع طيور معاملة

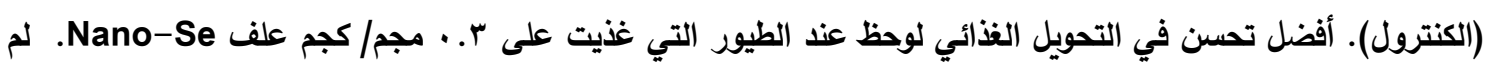

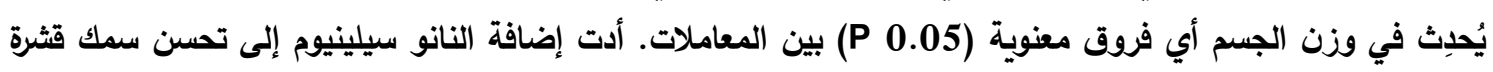

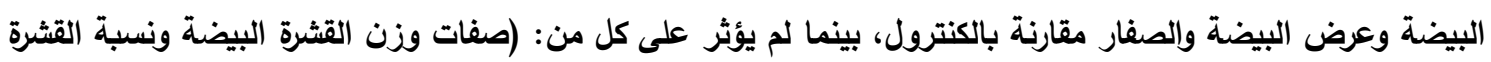

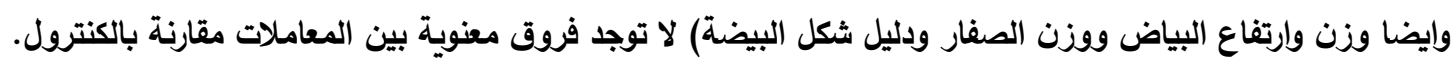

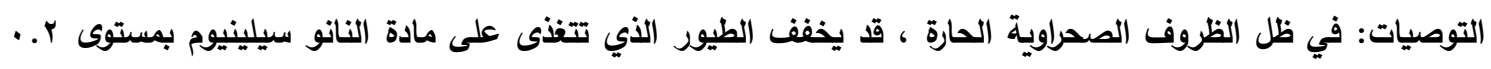

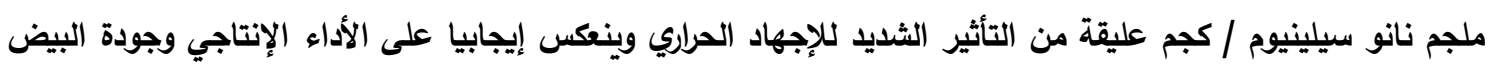
والكفاءة الاقتصادية والكفاءة النسبية.

أسماء السادة المحكمين

كلية الزراعة - جامعة المنوفية أ. أد/ جودة محمد جبريل عيلين

كلية الزراعة - جامعة الزقازيق

أ.د/ عادل إبراهيم عطية 